\title{
Improvement of Growth and Viability of Oreochromis niloticus in a Biofloc System Using Chlorella vulgaris
}

\author{
Nasser, S. Flefil ${ }^{1, *}\left(\mathbb{D}\right.$, Ahmed, M. Aboseif $^{1}\left(\mathbb{D}\right.$, Abd-Ellatif M. Hussian $^{2}$ \\ ${ }^{1}$ National Institute of Oceanography and Fisheries, Egypt. \\ ${ }^{2}$ Matrouh University, Faculty of Education, Marsa Matrouh, Egypt.
}

\section{How to cite}

Flefil, N.S., Aboseif, A.M., Hussian, A.M. (2021). Improvement of Growth and Viability of Oreochromis niloticus in a Biofloc System Using Chlorella vulgaris. Turkish Journal of Fisheries and Aquatic Sciences, 21, 491-500. http://doi.org/10.4194/1303-2712-v21_10_02

\section{Article History}

Received 13 August 2020

Accepted 02 June 2021

First Online 07 June 2021

\section{Corresponding Author}

Tel.: +201144782431

E-mail: naserflefil@yahoo.com

\section{Keywords}

Phytoplankton

Growth performance

Nile tilapia

Physico-chemical variables

\begin{abstract}
This study aimed to enhance Nile Tilapia growth using Chlorella vulgaris as a food additive in the biofloc system. Different concentrations of $C$. vulgaris were tested in four different treatments compared to control. The growth rate of Nile tilapia was parallel with $C$. vulgaris addition to the treatments. The best productive value (growth performance) for Nile Tilapia was recorded in T1 that was distinctly superior to the other treatments. The use of $C$. vulgaris in the biofloc system decreased feed conversion ratio (FCR) values; whereas the most significant value was observed at $\mathrm{T} 1$. Phytoplankton structure in Nile Tilapia gut was predominated with $C$. vulgaris representing $67.7 \%$ of the total phytoplankton crop. Statistical analysis also approved that the most important factor affecting Nile Tilapia growth was $C$. vulgaris addition, and some other chemical variables that affect phytoplankton's growth such as $\mathrm{PO}_{4}$. In addition, muscle protein ratio of Nile Tilapia increased with increasing $C$. vulgaris concentrations. Our data concluded that increasing C. vulgaris concentration improved the growth performance of Nile Tilapia under the biofloc condition.
\end{abstract}

\section{Introduction}

One of the most important fish species worldwide is Oreochromis niloticus (Nile tilapia) with about 4.2 million tons, representing $8 \%$ of fish aquaculture. World production of aquaculture outside aquatic plants reached 80 million tons in 2016, with inland fish aquaculture production representing 59.3\% (FAO, 2018).

Aquaculture is also of great significance because its production accounts for approximately $60 \%$ of the total aquatic protein used for human consumption. Still, as a rapidly growing market, it puts immense pressure on the aquaculture industry to find healthy and cost-effective ingredients in fish foods (Salin et al., 2018; Goda et al., 2020).

Biofloc technology (BFT) is an eco-friendly technique, contains whole essential nutrients, plays a vital role in water quality control and nutrient cycling in the culturing cell, in addition to improving water quality by converting ammonia to nitrate, reducing required dietary protein, reducing feed conversion ratio (FCR) and feed costs and improving fish health by competition with pathogens (Liñán-Cabello et al., 2002; Ju et al., 2008a; Ballester et al., 2010; Ray et al., 2011; Emerenciano et al., 2012a and b; Nimrat et al., 2013; Avnimelech, 2015; Emerenciano et al., 2017).

Microalgae is one of the most significant biotic factors shaping the thriving culture of Nile tilapia in semi-intensive ponds (Mbonde et al., 2017); hence phytoplankton is a source of natural feed for fish farming in the pond (Arifin et al., 2018). Phytoplankton can be used in fish feed to enhance fillet quality by deposition of n-3 polyunsaturated fatty acids and is considered a substitute for fish meal and fish oil in aquatic feeds (Sarker et al., 2016). 
One of the most frequently exploited phytoplankton species owing to its high protein content (about $51 \%-58 \%$ of its dry weight), is C. vulgaris. It contains essential amino acids (Becker, 2007), along with many other beneficial substances (RodriguezGarcia \& Guil-Guerrero, 2008), and can be used as a good protein source for African catfish and a substitute for fishmeal in catfish diets (Enyidi, 2017).

Therefore, using algae as an unconventional feed ingredient and feed additives in replacement of highcost feed materials such as fishmeal has been potentially increased (Badwy et al., 2008). Some microalgae in fish feeding experiments resulted in increased growth, physiological activity, and disease resistance (Roy \& Pal, 2015).

However, using $C$. vulgaris in the biofloc system still needs further study. Therefore, this study was designed to determine the efficacy of $C$. vulgaris in improving the growth and viability of Nile tilapia in the biofloc system and the sensitivity of fish growth to other factors.

\section{Material and Methods}

\section{Experimental Conditions}

This study was conducted in Fish Nutrition wet Lab, at fish research station, National Institute of Oceanography and Fisheries (NIOF), El- Kanater El khayria, Egypt, in plastic tanks (125L capacity filled to $100 \mathrm{~L}$ with water). The experiment was designed in triplicates, with four different treatments besides the control. The source of water was originally from a freshwater well. The tanks were operated with zero water exchange; however, water was added as needed to replace evaporated losses. The tanks were aerated by aquarium air pumps to maintain the proper oxygen level.

\section{Experimental Fish}

Nile Tilapia (Oreochromis niloticus), mono sex, was purchased from a commercial hatchery in Fayom Governorate (Egypt). Fish were acclimated to the experimental conditions for two weeks before the feeding trial. Fish initial body weights (IBW) were ranged from 6.05 to $6.68 \mathrm{~g}$. Fish were randomly assigned to 15 tanks (20 fish each). The treatments were designed in triplicate replication. Fish were weighted and their length was measured every two weeks through the experimental period (75 days). Fish were not fed at the weight day.

\section{Preparation of the Experimental Alga}

C. vulgaris was cultured in a Hydrobiology Lab in National Institute of Oceanography and Fisheries (NIOF), El- Kanater El khayria, Egypt. BG11 culture medium was used to grow C. vulgaris (Ilavarasi et al., 2011). Inoculation of $C$. vulgaris $\left(10^{3}\right.$ cells/ $\left.\mathrm{ml}\right)$ was done, through different interval times, in several $1500 \mathrm{~mL}$ flasks filled to $500 \mathrm{~mL}$ medium and under controlled conditions supported by a continuous air pump for aeration, temperature $24^{\circ} \mathrm{C} \pm 2^{\circ} \mathrm{C}, \mathrm{pH} 7.3$ and light intensity 2000 lux. (Measured at water surface) and a fluorescent lamp for 24-hour lighting.

\section{Diet and Feeding Protocol}

One practical diet was formulated as isonitrogenous (30\% crude protein) and isocaloric (20 $\mathrm{kj} / \mathrm{g}$ diet) for all treatments. Four different treatments (namely; T1, T2, T3, and T4) comprising four different volumes $(80,40,20$, and $10 \mathrm{ml}$, respectively) of $C$. vulgaris culture ( 8 days incubation, $5 \times 10^{5} \mathrm{cell} / \mathrm{ml}$ ) as a food additive were added simultaneously with the practical diet during the entire fish culture period. Fish were fed ad libitum twice daily at 9:00 am and 3:00 pm, five days a week. The control group received only the practical diet with the same feeding protocol.

Starch was used as a source of organic carbon in the biofloc system and added in a liquid form one time daily for five days a week. The total daily amount of carbon source was calculated according to (Hargreaves, 2013; Pérez-Fuentes et al., 2016).

\section{Water Quality}

Water quality variables were measured every week during the experimental period (75 days). Dissolved oxygen and temperature were monitored using a dissolved oxygen meter (Professional Plus, USA). pH was measured in the water column of the tanks by $\mathrm{pH}$ meter (HI 8314 model). The settleable solids were measured after 20 minutes by Imhoff cones (after filling the cone) (Avnimelech, 2009). Chemical

variables $\left(\mathrm{NH}_{4}, \mathrm{NO}_{2}, \mathrm{NO}_{3}, \mathrm{PO}_{4}\right.$, and Total Alkalinity) were estimated according to the procedures laid down in APHA (2017).

\section{Proximate Composition}

Diets, fish carcass, and biofloc samples were analyzed for dry matter (DM), ash content, crude protein $(\mathrm{N} \times 6.25)$ by the Kjeldahl method using a Kjeltech auto-analyzer according to AOAC (2012). Crude fat was measured according to Bligh \& Dyer (1959).

\section{Phytoplankton Identification and Enumeration}

Drop method was applied for counting and identifying phytoplankton species (APHA, 2017), triplicate samples $(5 \mu \mathrm{l})$ were taken and examined under inverted microscope ZEISS IM 4738, with magnification power 20 and 40x. The results of phytoplankton density were presented as the number of cells per liter (cell/l). Phytoplankton identification was performed according to Popovsky \& Pfiester, 1990; Krammer \& LangeBertalot, 1991; Edmondson, 1992; Verlencar \& Desai, 
2004; Lee, 2008; Bellinger \& Sigee, 2010 and 2015; Munshi et al., 2010.

\section{Statistical Analysis}

At the end of the experiment, data collected were subjected to one-way analysis of variance (ANOVA) using statistical software (SPSS 18) to detect significant differences in all parameters. Duncan's new multiple range tests (Duncan, 1955) was used to detect individual differences between treatment means. All data were represented as means \pm standard deviation (SD), and a rejection level of $(P>0.05)$ would be used for all statistical analysis.

Pearson's correlation was performed to assess the relationship between the increased growth rate of Nile tilapia with surrounding physical, chemical, and biological factors. These relations were also examined with a normalized principal component analysis (PCA).

\section{Results}

Distribution and abundance of phytoplankton in the biofloc system and Nile tilapia gut after $C$. vulgaris addition

Different concentrations of $C$. vulgaris were used and compared in this experiment. The results indicated that increasing $C$. vulgaris concentration enhanced the growth of phytoplankton in the biofloc system, and consequently, in tilapia's gut contents compared to control.

Through the experiment period, the maximum phytoplankton standing crop was observed at $\mathrm{T} 1$, that received the highest concentration of $C$. vulgaris, reaching about $46 \times 10^{6} \mathrm{cell} / \mathrm{I}$ and $173 \times 10^{6} \mathrm{cell} /$ gut in both biofloc system and tilapia gut, respectively. Their population density was gradually declined with the other treatments T2, T3, and T4. The least density of phytoplankton in both biofloc system and tilapia gut were reported with control treatment, recording $6 \times 10^{6} \mathrm{cell} / \mathrm{l}$ and $40 \times 10^{6} \mathrm{cell} / \mathrm{gut}$, respectively.

Phytoplankton composition, which grown in the biofloc system, was dominated with Chlorophyta, forming about $73.8 \%$ of the total phytoplankton density. While Bacillariophyta represented the second group concerning density, representing approximately $14.1 \%$. Charophyta, Euglenophyta, and Cyanobacteria were presented with low densities, reaching about $7.3 \%$, $3.0 \%$, and $1.8 \%$, respectively.

Studying the composition of phytoplankton in fish gut contents and the biofloc system revealed that it was more or less the same. It was predominated by Chlorophyta, forming about $80.6 \%$ of the total phytoplankton density found in fish gut, followed by Bacillariophyta with about $12.2 \%$ and Charophyta representing about $7.2 \%$.

The average density of $C$. vulgaris in tilapia gut and the biofloc system at the four different treatments during the experimental period is shown in Figure 1.
Phytoplankton abundance in the biofloc treatments and in tilapia gut during the present study revealed that the dominant species was $C$. vulgaris as shown in Tables 1 and 2 . The average percentages of $C$. vulgaris present in tilapia gut during the different treatments along the experimental period are shown in Figure 2.

Growth performance, feed efficiency, and survival rate of Nile tilapia

Growth performance increased with the increase of $C$. vulgaris addition in the biofloc system (Table 3 ). The best productive values for Nile tilapia were recorded in T1 and T2 treatments, which were distinctly superior to the other groups. The control group significantly recorded the lowest final average body weight of $28.47 \mathrm{~g}$ $(P \leq 0.05)$ among all dietary groups.

Fish fed with T3 treatment (Table 3) reported substantially higher feed intake compared to other treatments (44.36), while control and T4 treatment (34.84 and 37.45 , respectively) $(P \leq 0.05)$ recorded the lowest values compared to other treatments. Use of algae in the biofloc system decreased preferably the feed conversion ratio (FCR) values, whereas the most significant FCR (feed convertion ratio) values were observed for T1 and T2 treatments (1.28 and 1.47, respectively). In contrast, the insignificant values $(P \geq 0.05)$ were recorded for T3 (1.76) and T4 (1.65) treatments. Fish fed with $\mathrm{T} 1$ and $\mathrm{T} 2$ treatments recorded the highest significant PER (protein efficiency ratio) values (2.59 and 2.25, respectively). Otherwise, T3 had the lowest PER values (1.89 \%) (Table 3).

Concerning protein results for the present study, $\mathrm{T} 1$ and $\mathrm{T} 2$ treatments showed higher protein ratios than other treatments, while T2 and T3 treatments showed higher whole-body lipid levels than other treatments (Table 4).

Physico-chemical variables and biological correlations

The correlation matrix (Table 5) cleared that $\mathrm{PO}_{4}$ $(r=0.73, P<0.05)$ was a limiting growth factor for phytoplankton growth, especially $C$. vulgaris in a biofloc system.

Statistical analysis showed a significant positive correlation $(r=0.62, P<0.05)$ between Nile Tilapia growth rate and $C$. vulgaris density in the gut (Table 5).

PCA Figure 3 cleared that Nile Tilapia growth rate is highly coordinate positively with $\mathrm{PO}_{4}, \mathrm{NO}_{3}$, and alkalinity ( $r=0.90,0.80$, and 0.79 , respectively, $P<0.05$ ), and negatively with $\mathrm{pH}(\mathrm{r}=-0.85)$ and $\mathrm{DO}(r=-0.45)$.

\section{Discussion}

It was observed that using $C$. vulgaris as feed additive in the biofloc system led to the dominance of Chlorophyta (73.8\% of the total phytoplankton density). Hence in the gut of tilapia, forming about $80.6 \%$ of the total phytoplankton density in the gut. Our result showed that $C$. vulgaris represented a high average of $67.7 \%$ from tilapia's gut content along the experimental 
period. Ahmed et al. (2019) mentioned that phytoplankton communities in a biofloc system for Nile tilapia cultivation were dominated by Chlorophyceae. The current study showed that using $C$. vulgaris as a feed additive led to the increasing growth performance of Nile tilapia; this result agrees with Mahmoud et al. (2020). The best productive values (growth performance) for Nile tilapia were recorded in T1 that was distinctly superior to the other treatments. This could be due to the addition of the highest amount of $C$. vulgaris. Chlorella could be used as a good additive and could promote the growth performance and physiological parameters of gibel carp (Carassius auratus gibelio) (Zhang et al., 2014)

Statistical analysis indicated that the most important factor affecting Nile Tilapia growth was $C$. vulgaris addition, and some chemical variables that affect the growth of phytoplankton, especially $C$. vulgaris such as $\mathrm{PO}_{4}$ as mentioned by Ahmed et al. (2019).
As the results revealed, algae in the biofloc system reduced the feed conversion ratio (FCR) values significantly, whereas the most significant FCR values were observed at T1 and T2 treatments (1.28 and 1.47, respectively). These results were in agreement with the results of Emerenciano et al. (2017), who revealed that algae in the biofloc system play a vital role in reducing feed conversion ratio (FCR); this may be due to the high digestibility of $C$. vulgaris, resulting in stimulation of fish intestinal flora and subsequently increasing the activity of digestive enzymes and efficient diet use (Khani et al., 2017). Furthermore, fish that received the highest $C$. vulgaris concentration in $\mathrm{T} 1$ and $\mathrm{T} 2$ treatments recorded the most significant PER values (2.59 and 2.25, respectively). Giving that protein in $C$. vulgaris can reach up to $60 \%$, our obtained results indicated that it could be potentially used as a fish feed additive. Xu et al. (2014) showed that Chlorella could be a good choice as a fish feed due to the best crude protein level, a significant concentration of polysaccharides, lipid,

Table 1. List of phytoplankton species recorded in a biofloc system and their abundance during the experiment period.

\begin{tabular}{|c|c|c|c|c|c|}
\hline \multirow{2}{*}{ Species } & \multicolumn{5}{|c|}{ Biofloc system treatments } \\
\hline & Control & $\mathrm{T} 1$ & $\mathrm{~T} 2$ & T3 & $\mathrm{T} 4$ \\
\hline \multicolumn{6}{|l|}{ Phylum: Chlorophyta } \\
\hline Actinastrum hantzschii & - & - & + & + & + \\
\hline Ankistrodesmus falcatus & + & +++ & ++ & ++ & + \\
\hline Chlorella vulgaris & + & ++++ & ++++ & +++ & ++ \\
\hline Coelastrum microporum & + & + & - & - & - \\
\hline Crucigenia tetrapedia & + & ++ & + & ++ & + \\
\hline Eudorina elegans & - & + & - & - & - \\
\hline Kirchneriella lunaris & + & ++ & ++ & + & + \\
\hline Monactinus simplex & + & ++ & + & - & - \\
\hline Monoraphidium convolutum & + & +++ & ++ & + & + \\
\hline Nephrocytium limneticum & - & ++ & + & + & - \\
\hline Oocystis borgi & + & + & - & - & - \\
\hline Scenedesmus ecornis & - & + & - & + & + \\
\hline Schroederia jadayi & - & + & - & + & + \\
\hline Tetradesmus incrassatulus & - & ++ & + & - & - \\
\hline Tetraëdron minimum & + & ++ & - & + & - \\
\hline Tetraselmis suecica & + & ++ & + & - & ++ \\
\hline \multicolumn{6}{|l|}{ Phylum: Bacillariophyta } \\
\hline Amphora ovalis & - & + & - & - & + \\
\hline Aulacoseira granulate & + & - & - & + & + \\
\hline Cocconeis placentula & - & + & - & - & + \\
\hline Cyclotella meneghiniana & + & - & + & + & - \\
\hline Cymbella lanceolata & - & - & - & + & + \\
\hline Gyrosigma attenuatum & + & - & - & - & + \\
\hline Lyrella lyra & - & ++ & + & - & - \\
\hline Navicula radiosa & - & - & + & - & + \\
\hline Nitzschia linearis & - & ++ & + & - & + \\
\hline Nitzschia sigma & + & + & + & - & - \\
\hline Pantocsekiella ocellata & + & - & ++ & + & - \\
\hline Pinnularia major & + & + & + & - & - \\
\hline \multicolumn{6}{|l|}{ Phylum: Charophyta } \\
\hline Closterium sp. & + & ++ & + & + & + \\
\hline Cosmarium abbreviatum & + & + & - & - & - \\
\hline Elakatothrix gelatinosa & + & ++ & - & + & - \\
\hline Staurastrum anatinum & - & - & + & + & - \\
\hline \multicolumn{6}{|l|}{ Phylum: Euglenophyta } \\
\hline Phacus acuminatus & + & + & + & - & + \\
\hline \multicolumn{6}{|l|}{ Phylum: Cyanobacteria } \\
\hline Merismopedia elegans & + & ++ & + & + & + \\
\hline Total & 21 & 26 & 21 & 18 & 19 \\
\hline
\end{tabular}

Note: abscent (-), present (+), moderate abundance (++), high abundance (+++), very high abundance (++++) 
Table 2. List of phytoplankton species recorded in Nile Tilapia gut and their abundance during the experiment period.

\begin{tabular}{|c|c|c|c|c|c|}
\hline \multirow{2}{*}{ Species } & \multicolumn{5}{|c|}{ Tilapia gut treatments } \\
\hline & Control & $\mathrm{T} 1$ & $\mathrm{~T} 2$ & T3 & $\mathrm{T} 4$ \\
\hline \multicolumn{6}{|l|}{ Phylum: Chlorophyta } \\
\hline Actinastrum hantzschii & - & - & + & - & + \\
\hline Ankistrodesmus falcatus & + & + & + & + & + \\
\hline Chlorella vulgaris & + & ++++ & +++ & ++ & ++ \\
\hline Crucigenia tetrapedia & + & + & + & + & + \\
\hline Kirchneriella lunaris & + & ++ & + & - & - \\
\hline Monactinus simplex & + & + & + & - & - \\
\hline Monoraphidium convolutum & + & + & - & + & + \\
\hline Oocystis borgi & + & - & - & - & - \\
\hline Scenedesmus ecornis & - & + & - & - & + \\
\hline Tetradesmus incrassatulus & - & + & - & - & - \\
\hline Tetraëdron minimum & + & + & - & - & - \\
\hline Tetraselmis suecica & + & - & + & - & - \\
\hline \multicolumn{6}{|l|}{ Phylum: Bacillariophyta } \\
\hline Amphora ovalis & - & + & - & - & + \\
\hline Aulacoseira granulate & + & - & - & + & - \\
\hline Cyclotella meneghiniana & - & - & - & + & - \\
\hline Cymbella lanceolata & - & - & - & + & + \\
\hline Lyrella lyra & - & - & + & - & - \\
\hline Navicula radiosa & - & - & + & - & + \\
\hline Nitzschia linearis & - & + & + & - & - \\
\hline Pantocsekiella ocellata & - & - & + & - & - \\
\hline Pinnularia major & + & + & + & - & - \\
\hline \multicolumn{6}{|l|}{ Phylum: Charophyta } \\
\hline Closterium sp. & + & + & + & + & - \\
\hline Elakatothrix gelatinosa & + & + & - & + & - \\
\hline Staurastrum anatinum & - & - & + & + & - \\
\hline Total & 13 & 14 & 14 & 10 & 9 \\
\hline
\end{tabular}

Note: abscent (-), present (+), moderate abundance (++), high abundance $(+++)$, very high abundance (++++)

Table 3. Growth performance and feed efficiency of Nile tilapia through 75-days under biofloc condition.

\begin{tabular}{|c|c|c|c|c|c|}
\hline \multirow{2}{*}{ Parameters } & \multicolumn{5}{|c|}{ Treatments } \\
\hline & Control & T1 & $\mathrm{T} 2$ & T3 & T4 \\
\hline Final body weight (g) & $28.47 \pm 1.25^{c}$ & $37.01 \pm 1.69^{a}$ & $33.82 \pm 1.07^{a b}$ & $31.38 \pm 1.41^{b c}$ & $29.33 \pm 1.33^{b c}$ \\
\hline Gain (g) & $22.42 \pm 1.26^{\mathrm{b}}$ & $30.60 \pm 1.32^{a}$ & $27.07 \pm 1.03^{b c}$ & $25.15 \pm 0.74^{b}$ & $22.65 \pm 0.82^{b}$ \\
\hline SGR (\%/day) & $2.24 \pm 0.15^{\mathrm{ab}}$ & $2.59 \pm 0.03^{a}$ & $2.38 \pm 0.01^{\mathrm{ab}}$ & $2.33 \pm 0.07^{\mathrm{ab}}$ & $2.23 \pm 0.11^{\mathrm{b}}$ \\
\hline Feed intake (g) & $34.84 \pm 0.48^{c}$ & $39.33 \pm 1.83^{a}$ & $39.98 \pm 1.23^{\mathrm{ab}}$ & $44.35 \pm 0.46^{a}$ & $37.45 \pm 1.04^{\mathrm{bc}}$ \\
\hline FCR & $1.55 \pm 0.94^{\mathrm{abc}}$ & $1.28 \pm 0.18^{c}$ & $1.47 \pm 0.07^{b c}$ & $1.76 \pm 0.08^{\mathrm{a}}$ & $1.65 \pm 0.12^{\mathrm{a}}$ \\
\hline PER (\%) & $2.14 \pm 0.11^{\mathrm{abc}}$ & $2.59 \pm 0.13^{a}$ & $2.25 \pm 0.14^{\mathrm{ab}}$ & $1.89 \pm 0.09^{c}$ & $2.01 \pm 0.04^{\mathrm{bc}}$ \\
\hline
\end{tabular}

Note: Each value represents mean $\pm S D(n=3)$. Values within the same row with different superscript letters are significantly different $(P<0.05)$. Specific growth rate (SGR), feed conversion ratio (FCR) Protein efficiency ratio (PER), were calculated as follows: SGR (\%/day) = 100 (In W2 - In W1). TW2: The final weight of fish in $\mathrm{g}$. W1: is the initial weight of fish in $\mathrm{g}$. In: is the natural log. T: is the time in days. FCR = Feed intake (g)/ Weight gain (g). PER = Weight gain, g/ Protein intake, g.

Table 4. Whole-body composition (\% on dry matter basis $\mathrm{Dm}$ ) of Nile tilapia at the start and end of the experiment.

\begin{tabular}{lcccc}
\hline \multicolumn{1}{c}{ Treatments } & Moisture\% & Protein \% & Lipid (Ether Extract) \% & Ash\% \\
\hline Control & $82.84 \pm 0.46^{\mathrm{a}}$ & $56.78 \pm 1.79^{\mathrm{b}}$ & $11.22 \pm 0.91^{\mathrm{d}}$ & $26.08 \pm 0.18^{\mathrm{a}}$ \\
T1 & $81.35 \pm 0.68^{\mathrm{ab}}$ & $63.09 \pm 1.22^{\mathrm{a}}$ & $17.06 \pm 1.31^{\mathrm{b}}$ & $18.96 \pm 2.61^{\mathrm{b}}$ \\
T2 & $80.04 \pm 0.12^{\mathrm{bc}}$ & $62.18 \pm 0.83^{\mathrm{a}}$ & $18.71 \pm 0.50^{\mathrm{ab}}$ & $18.06 \pm 0.57^{\mathrm{b}}$ \\
T3 & $79.04 \pm 1.08^{\mathrm{c}}$ & $60.70 \pm 1.59^{\mathrm{ab}}$ & $19.83 \pm 1.45^{\mathrm{a}}$ & $18.87 \pm 0.62^{\mathrm{b}}$ \\
T4 & $80.04 \pm 1.49^{\mathrm{a}}$ & $59.97 \pm 2.04^{\mathrm{ab}}$ & $12.43 \pm 1.96^{\mathrm{c}}$ & $24.30 \pm 1.42^{\mathrm{a}}$ \\
Initial & $85.95 \pm 0.34$ & $61.86 \pm 0.9$ & $7.04 \pm 0.95$ & $24.93 \pm 0.45$ \\
\hline Note: Each value represents mean $\pm \mathrm{SD}(\mathrm{n}=3)$ Values in the same columns with different superscript letters are significantly different (P<0.05).
\end{tabular}

Note: Each value represents mean \pm SD $(n=3)$. Values in the same columns with different superscript letters are significantly different $(P<0.05)$. 


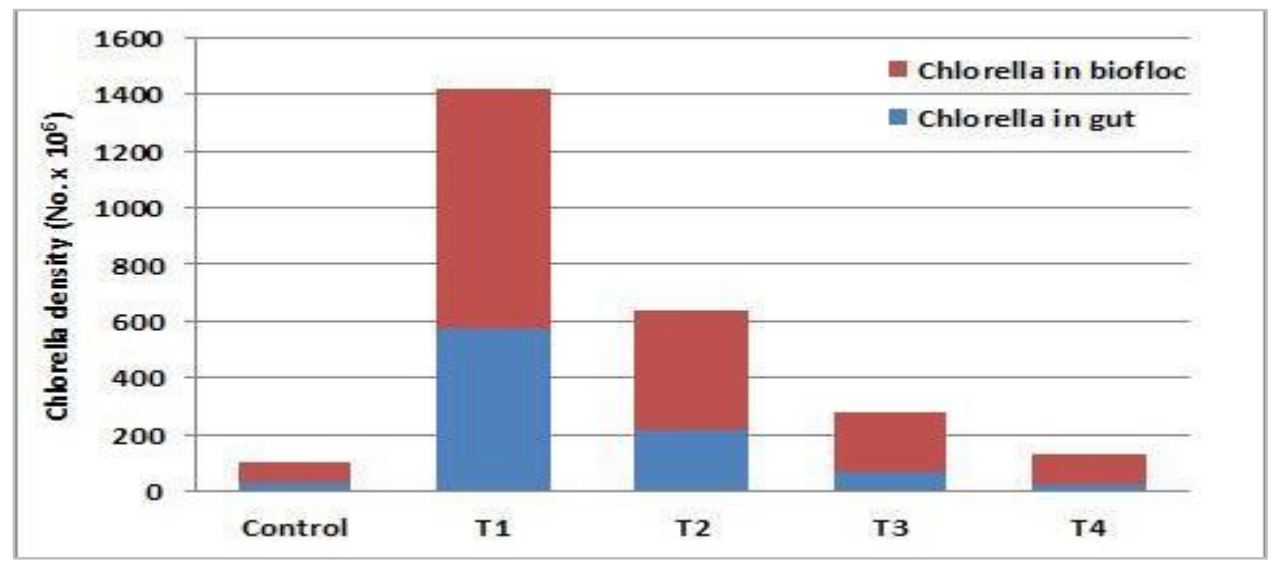

Figure 1. The average density of $C$. vulgaris in tilapia gut and in the biofloc system at different treatments

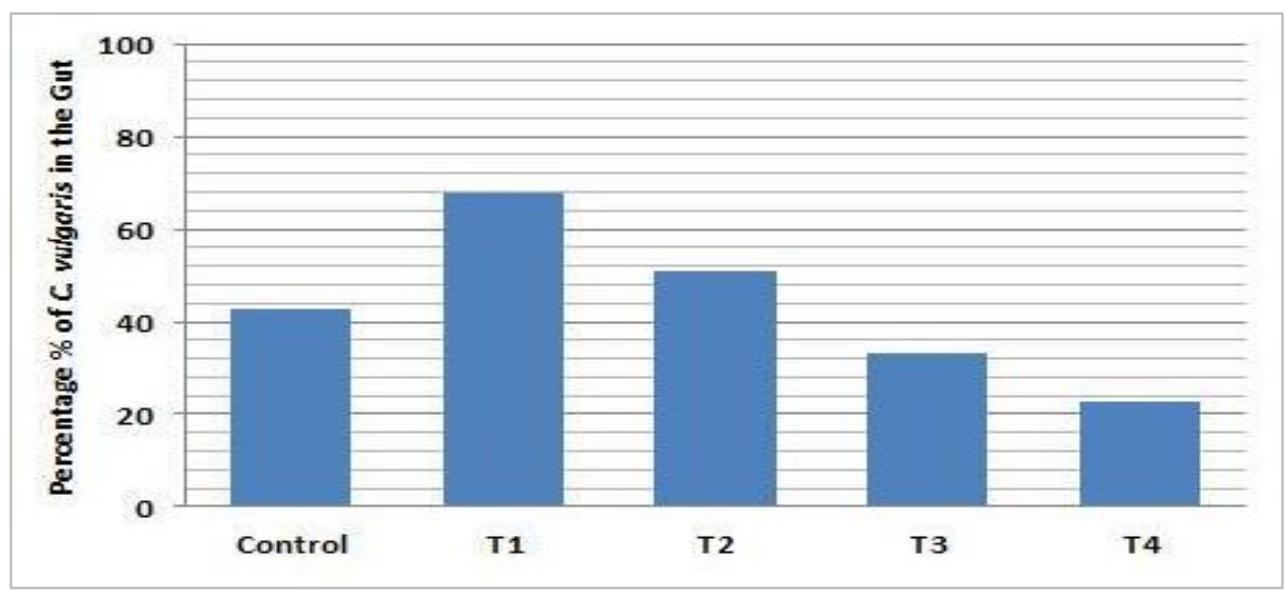

Figure 2. The percentage of $C$. vulgaris presence in tilapia gut at different treatments

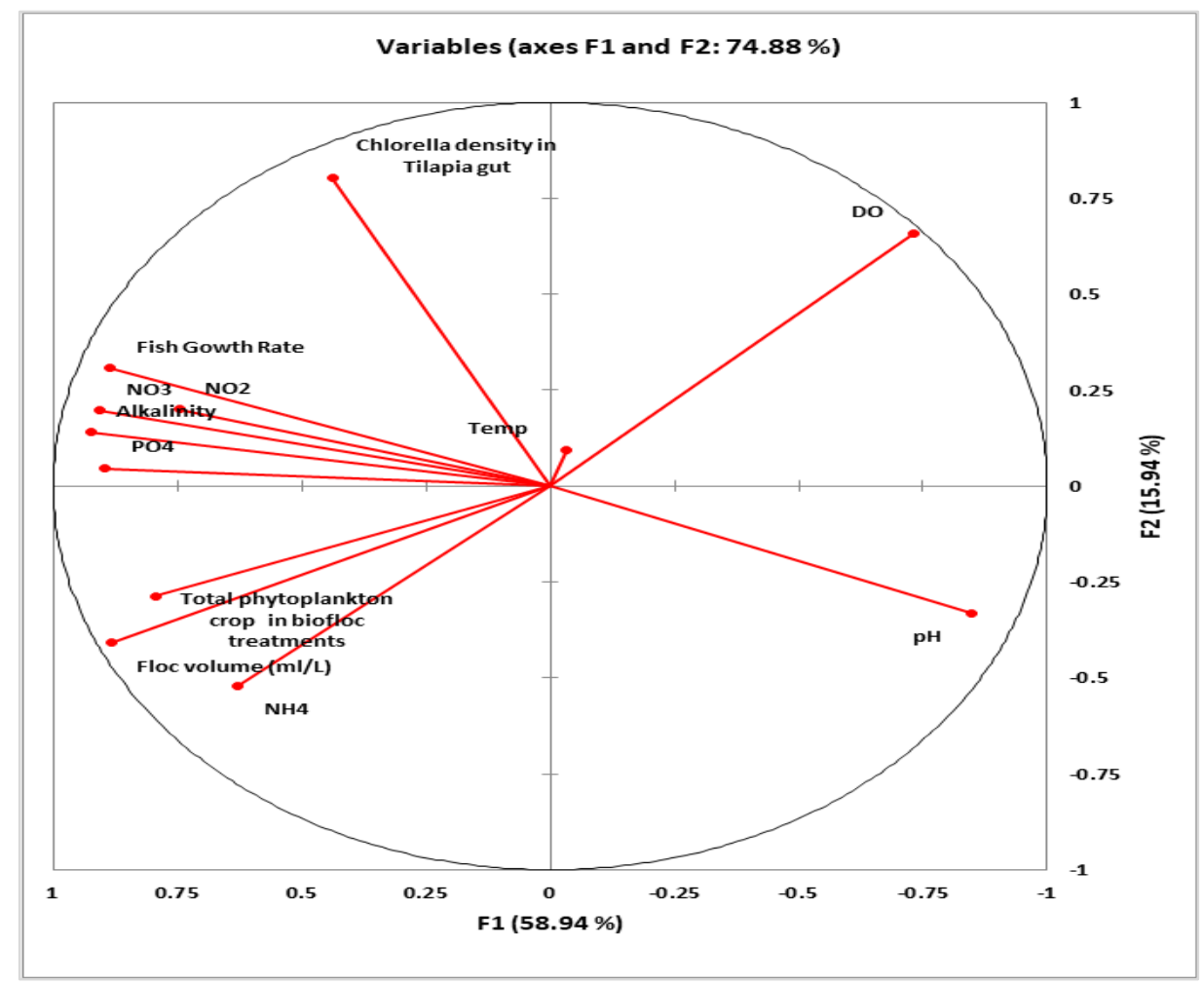

Figure 3. PCA performed on Nile tilapia growth rate, surrounding physico-chemical and biological factors 
Table 5. Pearson's correlation between Nile tilapia growth rate, surrounding physico-chemical and biological parameters.

\begin{tabular}{|c|c|c|c|c|c|c|c|c|c|c|c|c|}
\hline Variables & $\begin{array}{l}\text { Fish } \\
\text { Growth } \\
\text { Rate }\end{array}$ & $\mathrm{pH}$ & Temperature & DO & $\mathrm{NH}_{4}$ & $\mathrm{NO}_{2}$ & $\mathrm{NO}_{3}$ & $\mathrm{PO}_{4}$ & Alkalinity & $\begin{array}{l}\text { Floc } \\
\text { volume }\end{array}$ & $\begin{array}{l}\text { Chlorella } \\
\text { density } \\
\text { in Tilapia } \\
\text { gut }\end{array}$ & $\begin{array}{l}\text { Total } \\
\text { phytoplankton } \\
\text { crop in biofloc } \\
\text { treatments }\end{array}$ \\
\hline $\begin{array}{l}\text { Fish Growth } \\
\text { Rate }\end{array}$ & 1 & & & & & & & & & & & \\
\hline $\mathrm{pH}$ & -0.85 & 1 & & & & & & & & & & \\
\hline Temperature & -0.06 & 0.03 & 1 & & & & & & & & & \\
\hline DO & -0.45 & 0.44 & 0.13 & 1 & & & & & & & & \\
\hline $\mathrm{NH}_{4}$ & 0.26 & -0.39 & 0.10 & -0.79 & 1 & & & & & & & \\
\hline $\mathrm{NO}_{2}$ & 0.60 & -0.55 & -0.05 & -0.40 & 0.36 & 1 & & & & & & \\
\hline $\mathrm{NO}_{3}$ & 0.80 & -0.77 & -0.03 & -0.54 & 0.46 & 0.92 & 1 & & & & & \\
\hline $\mathrm{PO}_{4}$ & 0.90 & -0.86 & -0.05 & -0.64 & 0.50 & 0.45 & 0.69 & 1 & & & & \\
\hline Alkalinity & 0.79 & -0.75 & -0.08 & -0.58 & 0.51 & 0.90 & 0.96 & 0.71 & 1 & & & \\
\hline $\begin{array}{l}\text { Floc volume } \\
\text { (ml/L) } \\
\text { Chlorella }\end{array}$ & 0.72 & -0.63 & -0.11 & -0.92 & 0.69 & 0.50 & 0.69 & 0.81 & 0.72 & 1 & & \\
\hline $\begin{array}{l}\text { density in } \\
\text { Tilapia gut } \\
\text { Total }\end{array}$ & 0.62 & -0.66 & 0.15 & 0.22 & 0.03 & 0.34 & 0.47 & 0.48 & 0.46 & 0.06 & 1 & \\
\hline $\begin{array}{l}\text { phytoplankton } \\
\text { crop in biofloc } \\
\text { treatments }\end{array}$ & 0.68 & -0.52 & 0.17 & -0.71 & 0.58 & 0.45 & 0.57 & 0.73 & 0.64 & 0.84 & 0.15 & 1 \\
\hline
\end{tabular}

minerals, and other bioactive components involved in many physiological activities.

Concerning lipid contents, the results showed that lipid content varied with varying $C$. vulgaris concentrations, increased levels of $C$. vulgaris resulted in a gradual decrease in fish lipid content, this may be due to that lipid content of $C$. vulgaris is slightly low reaches approximately $12.5 \%$ (Blas-Valdivia et al. 2011). Giving fish a higher concentration of $C$. vulgaris resulted in decreasing the whole-body lipid levels. Our concluded results were consistent with that of Badwy et al. (2008), who stated that feed conversion ratio, growth performance, and productive protein values were more proficient in fish fed diets containing $50 \%$ of both Chlorella and Scenedesmus spp., moreover carcass analysis showed higher dry matter and crude protein content, but lower lipid content.

Protein results for the present study confirmed that the use of higher concentrations of phytoplankton ( $\mathrm{T} 1$ and $\mathrm{T} 2$ treatments) resulted in higher protein ratios than other treatments. This is attributed to the use of $C$. vulgaris as a dietary additive that resulted in enhancing tilapia's growth performance as mentioned by Maliwat et al. (2017).

Also, the increased concentration of phytoplankton in the biofloc system led to increased mean floc volume, as shown in $\mathrm{T} 1$ and $\mathrm{T} 2$ treatments compared to the control. Rajkumar et al. (2016) found that the floc volume in the first 15 days was slow due to the clean surfaces of the reservoir and the lower biological density at the start of the experiment. Then the volume increased gradually throughout the experiment, and the variance was constant over time.

\section{Conclusion}

Phytoplankton is the primary source of natural feed for Nile tilapia (Oreochromis niloticus) farming in the biofloc system. Introducing microalgae as a protein source might further increase aquaculture's efficacy and subsequently increasing human food production. From the data obtained, it could be concluded that increasing concentration of $C$. vulgaris in the biofloc system improved the growth performance of Nile tilapia under the biofloc condition.

\section{Ethical Statement}

All experiments were approved by NIOF Committee for ethical Care and Use of Animals/ Aquatic Animals (NIOF-IACUC) Egypt, with certificate code: NIOF-FW4-F-21-R-003.

\section{Funding Information}

No funding was received to assist with the preparation of this manuscript.

\section{Author Contribution}

Nasser Flefil is the author of the idea, cultivating and preparing chlorella vulgaris and adding it to fish feed, and he is involved with Abd-Ellatif Hussian in developing the design of the algae concentrations, Ahmed Aboseif bought and raised fish, set up a biofloc system, calculated feed, analyzed fish growth parameters, and ANOVA statistical analysis. Abd-Ellatif 
Hussian made Pearson correlation and PCA. All authors are involved in writing and reviewing this manuscript.

\section{Conflict of Interest}

The authors declare that they have no potential conflict of interest to report with respect to the research, authorship and publication of this article.

\section{Acknowledgements}

This work was supported by the National Institute of Oceanography and Fisheries (NIOF), Inland Water Branch, Hydrobiology and Fish Nutrition Departments, El- Kanater El khayria, Egypt.

\section{References}

Ahmed, N.M., Flefil, N.S., Tayel, S.I., Mahmoud, S.A., \& Soliman, A. (2019). Biological treatment of ammonia using biofloc system for Oreochromis niloticus fish. Egyptian Journal of Aquatic Biology and Fisheries, 23(4), 639 - 657. http://doi.org/10.21608/ejabf.2019.60912.

AOAC (2012). Official methods of analysis. 19th ed. Gaithersburg: AOAC. 3000p.

APHA (2017). Standard Methods for the examination of water and wastewater. $23^{\text {rd }}$ ed. Washington: $1546 \mathrm{pp}$.

Arifin, N.B., Fakhri, M., Yuniarti, A., \& Hariati, A.M. (2018). Phytoplankton community at intensive cultivation system of whiteleg shrimp, Litopenaeus vannamei in Probolinggo, East Java. International Journal of Fisheries and Aquatic Studies, 6(2), 42-46.

https://doi.org/10.18860/elha.v6i3.4800.

Avnimelech, Y. (2009). Biofloc technology: a practical guidebook. Baton Rouge: The World Aquaculture Society, $182 \mathrm{p}$.

Avnimelech, Y. (2015). Biofloc Technology, a Practical Guidebook, $3^{\text {rd }}$ Edition, World Aquaculture Society, 258p.

Badwy, T.M., Ibrahim, E.M., \& Zeinhom, M.M. (2008). Partial Replacement of Fish Meal with Dried Microalga (Chlorella spp and Scenedesmus spp) in Nile Tilapia (Oreochromis niloticus) Diets. In $8^{\text {th }}$ International Symposium on Tilapia in Aquaculture, Egypt, pp. 801811.

Ballester, E.L., Abreu, P.C., Cavalli, R.O., Emerenciano, M., Abreu, L., \& Wasielesky, W. (2010). Effect of practical diets with different protein levels on the performance of Farfantepenaeus paulensis juveniles nursed in a zero exchange suspended microbial flocs intensive system. Aquaculture Nutrition, 16:163-172. https://doi.org/10.1111/j.1365-2095.2009.00648.x.

Becker, E. W. (2007). Micro-algae as a source of protein. Biotechnology Advances, 25: 207-210. https://doi.org/10.1016/j.biotechadv.2006.11.002.

Bellinger, E.G., \& Sigee, D.C. (2010). Freshwater algae: Identification and use as bioindicators. $1^{\text {st }}$ edition by John Wiley and Sons, Ltd, 284 pp.

Bellinger, E.G., \& Sigee, D.C. (2015). Freshwater algae: Identification, Enumeration and use as bioindicators. $2^{\text {nd }}$ edition by John Wiley and Sons, Ltd, 290 pp.

Blas-Valdivia, V., Ortiz-Butrn, R., Pineda-Reynoso, M., Hernndez-Garcia, A., \& Cano-Europa, E. (2011). Chlorella vulgaris administration prevents $\mathrm{HgCl}_{2}$ caused oxidative stress and cellular damage in the kidney. Journal of Applied Phycology, 23, 53-58.

https://doi.org/10.1007/s10811-010-9534-6.

Bligh, E.G., \& Dyer, W.J. (1959). A rapid method for total lipid extraction and purification. Canadian Journal of Biochemistry and Physiology, 37: 911- 917. https://doi.org/10.1139/o59-099.

Duncan, D.B. (1955). Multiple range and multiple $F$ test. Biometrics,11, 1-42. https://doi.org/10.2307/3001478.

Edmondson, W.T. (1992). Ward and Whipple's Freshwater biology, $2^{\text {nd }}$ edition. John Wiley and Sons, New York, $\mathrm{p}$ 1248.

Emerenciano, M., Ballester, E.L., Cavalli, R.O., \& Wasielesky, W. (2012a). Biofloc technology application as a food source in a limited water exchange nursery system for pink shrimp Farfantepenaeus brasiliensis Latreille, 1817. Aquaculture Research, 43(3), 447-457. https://doi.org/10.1111/j.1365-2109.2011.02848.x.

Emerenciano, M., Cuzon, G., Goguenheim, J., Gaxiola, G., \& Aquacop, (2012b). Floc contribution on spawning performance of blue shrimp Litopenaeus stylirostris. Aquaculture Research, 44, 75-85.

https://doi.org/10.1111/j.1365-2109.2011.03012.x

Emerenciano, M., Martinez-Córdova, L.R., Martínez-Porchas, M., \& Miranda-Baeza, A. (2017). Biofloc technology (BFT): a tool for water quality management in aquaculture. In: Water quality. Tutu H. (ed), Intech Open, http://dx.doi.org/10.5772/66416

Enyidi, U.D. (2017). Chlorella vulgaris as Protein Source in the Diets of African Catfish Clarias gariepinus. Fishes, 2, 17. https://doi.org/10.3390/fishes2040017.

FAO (2018). The state of world fisheries and aquaculture 2018: Meeting the sustainable development goals. Rome: FAO. $227 p$.

Goda, A.M., Ahmed, S.R., Nazmi, H.M., Aboseif, A.M., Taha, M.K., Fadda, S.H., Baromh, M.Z., El-Haroun, E., \& Davies, S. (2020). Assessment of a high protein distillers dried grain (HP-DDG) augmented with phytase in diets for European sea bass, Dicentrarchus labrax fingerlings on growth performance, haematological status, immune 
response and related gut and liver histology. Aquaculture, 529, In press. 735617.

https://doi.org/10.1016/j.aquaculture.2020.735617.

Hargreaves, J.A. (2013). Biofloc Production Systems for Aquaculture. Southern Regional Aquaculture Center. (SRAC) Publication No. 4503, p. 1-12.

https://aquaculture.ca.uky.edu/sites/aquaculture.ca.uk y.edu/files/srac_4503_biofloc_production_systems_for aquaculture.pdf.

Ilavarasi, A., Mubarakali, D., Praveenkumar, R., Baldev, E., \& Thajuddin, N. (2011). Optimization of various growth media to freshwater microalgae for biomass production. Biotechnology, 10, 540-545.

10.3923/biotech.2011.540.545

Ju, Z.Y., Forster, I.P., Conquest, L., Dominy, W., Kuo, W.C., \& Horgen, F.D. (2008a). Determination of microbial community structures of shrimp floc cultures by biomarkers and analysis of floc amino acid profiles. Aquaculture Research, 39, 118-133. https://doi.org/10.1111/j.1365-2109.2007.01856.x.

Khani, M., Soltani, M., Shamsaie Mehrjan, M., Foroudi, F., \& Ghaeni, M. (2017). The effects of Chlorella vulgaris supplementation on growth performance, blood characteristics, and digestive enzymes in Koi (Cyprinus carpio). Iranian Journal of Fisheries Sciences, 16(2), 832843. http://aquaticcommons.org/23121/1/IFROv16n2p832-en.pdf.

Krammer, K., \& Lange-Bertalot, H. (1991). Bacillariophyceae. 3. Teil: Centrales, Fragilariaceae, Eunotiaceae In Ettl, H., Gerloff, J., Heynig, H. \& Mollenhauer, D. (Eds.). Süsswasserflora von Mitteleuropa. 2(3): 1-576. Gustav Fisher Verlag, Stuttgart, Germany.

Lee, R.E. (2008). Phycology. $4^{\text {th }}$ Edition. Cambridge University Press, New York. 547 pp.

Liñán-Cabello, M.A., Paniagua-Michel, J., \& Hopkins, P.M. (2002). Bioactive roles of carotenoids and retinoid in crustaceans. Aquaculture Nutrition, 8, 299-309. https://doi.org/10.1046/j.1365-2095.2002.00221.x.

Mahmoud, E.A., El-Sayed, B.M., Mahsoub, Y.H., El-Murr, A.I., \& Neamat-Allah, A.N. (2020). Effect of Chlorella vulgaris enriched diet on growth performance, hematoimmunological responses, antioxidant and transcriptomics profile disorders caused by deltamethrin toxicity in Nile tilapia (Oreochromis niloticus). Fish \& Shellfish Immunology, 102, 422-429.

https://doi.org/10.1016/j.fsi.2020.04.061.

Maliwat, G.C., Velasquez, S., Robil, J.L., Chan, M., Traifalgar, R.F., Tayamen, M., \& Ragaza, J.A. (2017). Growth and immune response of giant freshwater prawn Macrobrachium rosenbergii (De Man) postlarvae fed diets containing Chlorella vulgaris (Beijerinck). Aquaculture Research, 48, 1666-1676. https://doi.org/10.1111/are.13004.

Mbonde, A.S., Limbu, S.M., Shoko, A.P., \& Mgaya, Y.D. (2017). Phytoplankton and food selectivity in Nile tilapia reared in earthen ponds under monoculture and polyculture with African sharptooth catfish. Journal of Aquaculture in the Tropics, 32(1), 15-38.

https://www.researchgate.net/publication/317240586.

Munshi, J.D., Roy, S.P., \& Munshi, D. (2010). Manual of Freshwater biota. Narendra Publising House, Delhi, p. 1455.

Nimrat, S., Tanutpongpalin, P., Sritunyalucksana, K., Boonthai, T., \& Vuthiphandchai, V. (2013). Enhancement of growth performance, digestive enzyme activities and disease resistance in black tiger shrimp (Penaeus monodon) post larvae by potential probiotics. Aquaculture International, 21, 655-666. https://doi.org/10.1007/s10499-012-9600$y$.

Pérez-Fuentes, J. A., Hernández-Vergara, M. P., Pérez-Rostro, C. I., \& Fogel, I. (2016). C: N ratios affect nitrogen removal and production of Nile tilapia Oreochromis niloticus raised in a biofloc system under high density cultivation. Aquaculture, 452, 247-251.

https://doi.org/10.1016/j.aquaculture.2015.11.010.

Popovsky, J. \& Pfiester, L. (1990). Dinophyceae (Dinoflagellitida) subwasserflora von Mitteleuropa. Herausgegeben von. H. Ettl J. Gerloff. H. Heynig D. Mollenhauer. Band 6 Gustav Fischer Verlag. Jena, Stuttgart. pp: 272.

Rajkumar, M., Pandey, P.K., Aravind, R., Vennila, A., Bharti, V., \& Purushothaman, C.S. (2016). Effect of different biofloc system on water quality, biofloc composition and growth performance in Litopenaeus vannamei (Boone, 1931). Aquaculture Research, 47(11), 3432-3444. https://doi.org/10.1111/are.12792.

Ray, A.J., Dillon, K.S., \& Lotz, J.M. (2011). Water quality dynamics and shrimp (Litopenaeus vannamei) production in intensive, mesohaline culture systems with two levels ofbiofloc management. Aquaculture Engineering, 45(3), 127-136.

https://doi.org/10.1016/j.aquaeng.2011.09.001.

Rodriguez-Garcia, I., \& Guil-Guerrero, J.L. (2008). Evaluation of the antioxidant activity of three microalgal species for use as dietary supplements and in the preservation of foods. Food Chemistry, 108(3), 1023-1026. https://doi.org/10.1016/j.foodchem.2007.11.059.

Roy, S.S., \& Pal, R. (2015). Microalgae in aquaculture: a review with special references to nutritional value and fish dietetics. Proceedings of the Zoological Society, 68: 1-8. https://doi.org/10.1007/s12595-013-0089-9.

Salin K.R., Arun V.V., Nair C.M., \& Tidwell J.H. (2018). Sustainable Aquafeed. In: Hai F., Visvanathan C., Boopathy R. (eds) Sustainable Aquaculture. Applied 
Environmental Science and Engineering for a Sustainable Future. Springer, Cham. https://doi.org/10.1007/978-3319-73257-2_4.

Sarker, P.K., Gamble, M.M., Kelson, S., \& Kapuscinski, A.R. (2016). Nile tilapia (Oreochromis niloticus) show high digestibility of lipid and fatty acids from marine Schizochytrium $s p$. and of protein and essential amino acids from freshwater Spirulina $s p$. feed ingredients. Aquaculture Nutrition, 22, 109-119. https://doi.org/10.1111/anu.12230.

Verlencar, X.N., \& Desai, S.R. (2004). Phytoplankton identification Manual. National Institute of
Oceanography, Dona Paula. 35pp.

Xu, W., Gao, Z., Qi, Z., Qiu, M., Peng, J., \& Shao, R. (2014). Effect of dietary Chlorella on the growth performance and physiological parameters of gibel carp, Carassius auratus gibelio. Turkish Journal of Fisheries and Aquatic Sciences, 14, 53-57.

Zhang, Q., Qiu, M., Xu, W., Gao, Z., Shao, R., \& Qi, Z. (2014). Effects of Dietary Administration of Chlorella on the Immune Status of Gibel Carp, Carassius auratus gibelio, Italian Journal of Animal Science, 13(3), 3168, https://doi.org/10.4081/ijas.2014.3168. 